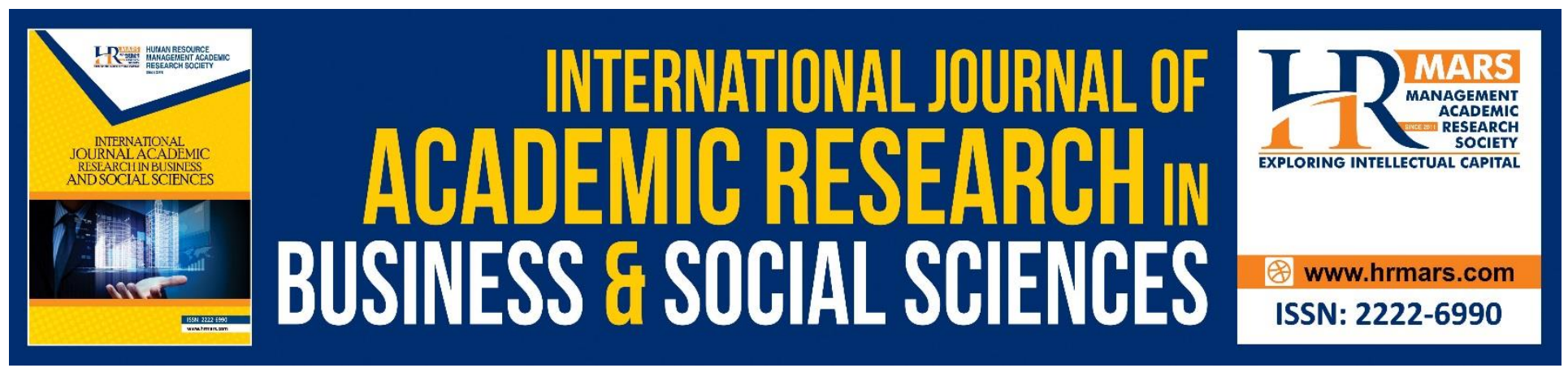

\title{
The Effect of Employee Engagement on Quality Work Task Performance with the Moderating role of Employee Relationship
}

Fiza Farooq, Muhammad Zia-ud-Din, Bushra Iram, Muhammad Tahir Nadeem

To Link this Article: http://dx.doi.org/10.6007/IJARBSS/v8-i8/4467

DOI: $\quad 10.6007 /$ IJARBSS/v8-i8/4467

Received: 17 July 2018, Revised: 07 August 2018, Accepted: 22 August 2018

Published Online: 30 August 2018

In-Text Citation: (Farooq, Zia-ud-Din, Iram, \& Nadeem, 2018)

To Cite this Article: Farooq, F., Zia-ud-Din, M., Iram, B., \& Nadeem, M. T. (2018). The Effect of Employee Engagement on Quality Work Task Performance with the Moderating role of Employee Relationship. International Journal of Academic Research in Business and Social Sciences, 8(8), 252-263.

Copyright: (c) 2018 The Author(s)

Published by Human Resource Management Academic Research Society (www.hrmars.com)

This article is published under the Creative Commons Attribution (CC BY 4.0) license. Anyone may reproduce, distribute, translate and create derivative works of this article (for both commercial and non-commercial purposes), subject to full attribution to the original publication and authors. The full terms of this license may be seen

at: http://creativecommons.org/licences/by/4.0/legalcode

Vol. 8, No. 8, August 2018, Pg. 252 - 263

http://hrmars.com/index.php/pages/detail/IJARBSS

JOURNAL HOMEPAGE

Full Terms \& Conditions of access and use can be found at http://hrmars.com/index.php/pages/detail/publication-ethics 


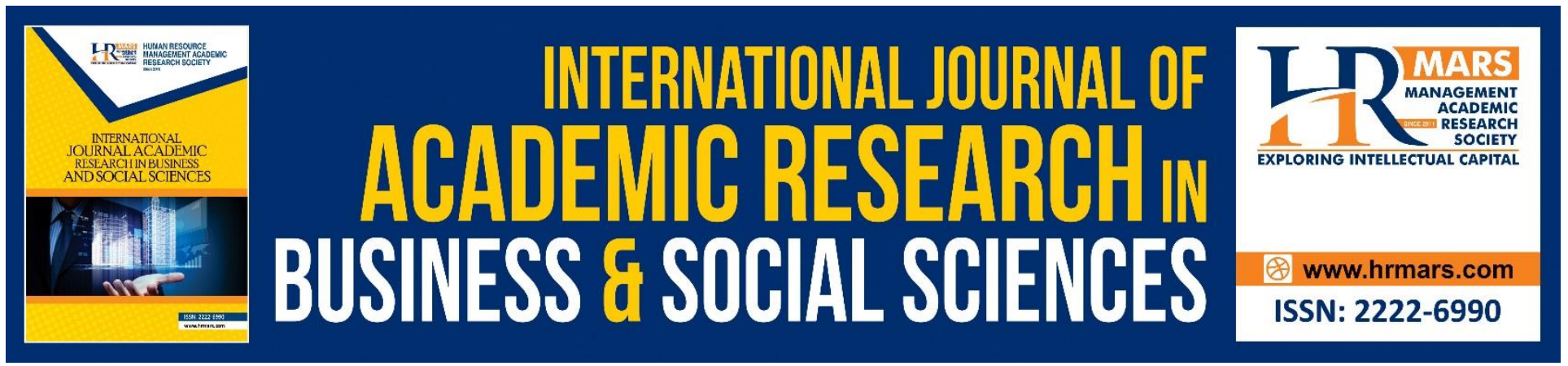

\title{
The Effect of Employee Engagement on Quality Work Task Performance with the Moderating role of Employee Relationship
}

\author{
Fiza Farooq \\ (Corresponding Author) \\ MPhil Scholar (Department of Public Administration), Government College University Faisalabad \\ Email: farooqfiza3@gmail.com \\ Muhammad Zia-ud-Din \\ Lecturer (Department of Public Administration), Government College University Faisalabad \\ Email: zeeyah4@hotmail.com \\ Bushra Iram \\ MPhil Scholar (Department Public Administration), Government College University Faisalabad, \\ Pakistan \\ Email: Bushrarajpoot602@yahoo.com \\ Muhammad Tahir Nadeem \\ MPhil Scholar (Department Public Administration), Government College University Faisalabad, \\ Pakistan \\ Email: tahirn82447@gmail.com
}

\begin{abstract}
This study tried to inquire the impact of employee engagement on task performance. In this study, moderation role of employee relationship between employee engagement and task performance is also being inquired. This survey is based on questionnaire and data is collected from 125 employee of textile sector organizations located in Faisalabad. The results of this study reveal that employee engagement and task performance are significantly correlated. Results reveal that significant. Thus, all the hypotheses showed significant results. This study will provide a guideline to organization management in considering the fusion/ Engagement of employees for attaining organizational goals. This study will guide the organization's management to figure out the role of Employee employees for the forthcoming cut-throat challenges in international business competition.
\end{abstract}


INTERNATIONAL JOURNAL OF ACADEMIC RESEARCH IN BUSINESS AND SOCIAL SCIENCES

Vol. 8, No. 8, August 2018, E-ISSN: 2222-6990 C 2018 HRMARS

Keywords: Employee Engagement, Task Performance, Employee Relation

\section{Introduction}

According to the Trends in worldwide Employee Engagement (2017) the imperative increases of employee engagement in 2016 have been incompletely erase (Bailey, Madden, Alfes, \& Fletcher, 2017). Populist actions like those seen in the United States, United Kingdom and individuals taking hold in part of Continental Europe have made debate on erect limits also walls more general (Anitha, 2014). Employee engagement spiky in 2015 but it gets be wipe left by a two point down in 2016 (Johnson, Robertson, \& Cooper, 2018). According the IBM The Many Context of Employee Engagement, employee engagement trends be based on a six nations example (US, UK, Germany, China, India brazil). Employee engagement material a huge contract by organizational leaders and human resources (HR) professionals, primarily, it is a situation that exists in the employee (Potoski, \& Callery, 2018). An employee's engagement is efficient, also straight or ultimately, to a few stages each and every one these relative page- the similar as repeal wave outcome (Schaufeli, Salanova, González-Romá, \& Bakker, 2002According to the ORC Global Perspective 2015 World Wide Trends in Employee Engagement at ORC global compute employee engagement by using the model 'say, stay, and strive'. Globally employee engagement is in this year $61 \%$ and it's up two points since the last year and breaking the $60 \%$ hurdle for the first time since our analysis began (Baumeister, \& Leary, 1995). This development has been reflected in all countries instead of Singapore and Switzerland (both down two points), Netherlands (it is down four points), Sweden (it is down five points) and Austria respectively (it is down ten points).

According To the report on employee engagement in Karachi's Pharmaceutical industry that is only $20 \%$ is less than one fourth of Karachi's Pharma employees are engaged, not engaged are $22 \%$ and $58 \%$ are more than employees are dis-engaged. According Shabbir, Ishtiaq and Zia-ud-Din, (2017) to the employee engagement in banking sector of Pakistan distributive honesty can cause $34.6 \%$ variation in employee engagement. They show that interactional honesty has constructive pressure on employee engagement and can cause $11.5 \%$ difference in employee engagement. To the report Gallup Pakistan HR, the newsletter survey begins that various companies demanded it to engage in engagement and eliminated the financial outcome resulting from its accident: more than $50 \%$ of companies were told that these companies were like business practices matrix Comparison of employee engagement more effectively or increasing market share (Macey, \& Schneider, 2008). 71\% of respondents described employee engagement as a very important role in achieving overall organizational success. $72 \%$ percent respondents have made significant impact on employee engagement.

More specifically, the aim of current research is to observe the effect of employees' engagement on task performance and investigate the moderating role of employee relationship.

\section{Problem Statement}

Now a day's organizations are determined towards transference and engagement of employees in organizations is the main issues that influence its performance. Nowadays there is a need to pick up the engagement stage of employee to gather their competitors particularly in the textile sector of Pakistan. So, the administration of the organization may exhibit in a way to engage the employees for achieving high performance in textile sector organizations in Pakistan. 
INTERNATIONAL JOURNAL OF ACADEMIC RESEARCH IN BUSINESS AND SOCIAL SCIENCES

Vol. 8, No. 8, August 2018, E-ISSN: 2222-6990 @ 2018 HRMARS

\section{Significance of Study}

This research is going to recover employee relationship through employee engagement. This study is depicting activist crash of employee engagement on employee relationship. This study helps the organization leader to accept employee engagement to resolve organizational issues to get organizational objectives. There are lots of new troubles faced by textile division organizations in Pakistan which is disturbing output. Energy crises, joblessness, machinery also competitors are mainly major troubles in the textile division organizations of Pakistan. According to Pakistan Bureau of Statistics (PBS), deal data through the economic year 2015-16, textile division of Pakistan practiced a huge refuse. According to PBS, Pakistan textile sell abroad is declined 7.42 percent from 2015 to 2016. The acceptance of employee engagement method in the textile division organizations is able to determine textile division organization's troubles. This study is an important plan for senior leaders in implementing strategies effectively by realizing the employee behavior. The plan of employee engagement is to develop relationship of employee by adopting a latest employee approach. The execution of employee engagement method in an organization will get better fulfillment stage of employees.

\section{Statement of Purpose}

Employee engagement approach is gauged from the reality that organizations are lurching towards delegation and workers are expectant that their leaders should display supportive part rather than decision-making. Therefore, employee engagement would support the employee behavior in consonance with rising delegation and consciousness among the employees. This study is supportive for organization to improve employee relationship and work task performance.

\section{Research Questions}

RQ1: What is the effect of EE (employees engagement) on TP (task performance)?

RQ2: What is the effect of EE on TP under the moderating role of employee-relationship?

\section{Objective of the Study}

The objectives are made by considering the Research Questions

- To evaluate the influence of EE on task performance.

- To Inquire the association between EE on task performance consideration into the moderating role of employee relationship.

\section{Literature Review}

\section{Employee Engagement}

Engagement has been used like a range of moment in various study such as 'worker engagement' (Macey and Schneider, 2008), 'persons engagement' (Kahn, 1990), 'labour engagement'. Kahn (1990) has describe employees engagement as "the link of member of organizational characters in their work roles; and in engagement, employees express their selves physically, emotionally, and cognitively during the role of performances". According to Zia-ud-Din, Shabbir, Asif, Bilal and Raza (2017) Management or leadership of an organization play an important role in the engagement at the level of employee working in the different organizations.

Employee engagement is somewhat stylish or whatever it can say, "the old wine in the new bottle" has been formed (Opoku-Dakwa, Chen, \& Rupp, 2018). Depending on the struggle for educational work based on the social roles. An employee's behavior can be measured by studying on 
INTERNATIONAL JOURNAL OF ACADEMIC RESEARCH IN BUSINESS AND SOCIAL SCIENCES

Vol. 8, No. 8, August 2018, E-ISSN: 2222-6990 @ 2018 HRMARS

individual. Schaufeli et al. (2002) stated that engagement as a psychological process "as promotive, fulfilling, work related cognitive state that is characterized by energy, dedication, and absorption". Employees are very strong perspective full of positive energy and are intellectual and physically strong. Engagement is a type of physical tendency that involves personal activity, is included to improve its performance (Huang, Lee, McFadden, Murphy, Robertson, Cheung, \& Zohar, 2016). Explain that engagement is the purpose of an employee whose work is involved in his work. This is a positive attitude that is employed in the job when he receives organizational support and cultural support (Rupp, Shao, Skarlicki, Paddock, Kim, \& Nadisic, 2018).

\section{Employee Relationship}

Everyone has an inherent need to work and maintain positive relationships. Because relationships bring the purpose of life, fulfill the desire to belong, and make the way people can live happy (Sias, Heath, Perry, Silva, \& Fix, 2004). These works pointing out the conversion patterns between two members or partners, whether organizations, groups or individuals are usually directed to achieve some goals or goals (Smothers, Doleh, Celuch, Peluchette, \& Valadares, 2016). Workshop relationships are important in organizations, because workers are mostly spent with other jobs (Maslach, 2003). Workshop relationships also help workers access resources and access career opportunities (Eldor, \& Vigoda-Gadot, 2017). Additionally, work-related employees help individual, organizational identities and professional Change the way to work to make their work more reliable and 'to see their jobs through' influence sharing, decisions making, conspiracy and emotional support systems'. It is considered to be abstract as an association of organizations (Trefalt, 2013).

According to leader member exchange (LMX) theories, there are different relationships with the supervisors. At the one side of the organization are low quality relations which are dangerous work environment crucial interaction that force a physiological and enthusiastic toll on people within the working environment (Yu, Mai, Tsai, \& Dai, 2018). And the second side high quality workplace relations are based on mutual trust and responsibility thus activate built-in inspiration (Yu et al., 2018). It results that tall quality working environment relation carries high levels of bolster and consideration than low quality relation, high-quality work environment relation generates more prominent result (Besieux, Baillien, Verbeke, \& Euwema, 2018). It is clear in research that has demonstrated regularly that the leader's lead scale achieves maximum results than at the bottom of the scale because previous leaders have taken their followers individually grain and Provide trust and support that is ideally provided with effect dimensions (Reader, Mearns, Lopes, \& Kuha, 2017). The fact is that employees are spending more time with their fellow colleagues, and then they are far more accessible than managers (Supanti, Butcher, \& Fredline, 2015). Organizations are beneficial for many reasons. First of all, co-workers provide emotional support with their passion and help in career development (Dhanesh, 2014). Next, co-workers deliver their colleagues for work and institutional knowledge needs to achieve their tasks well (Eldor, \& Vigoda-Gadot,2017). And finally, employees' relationships are important because fellow employees are considered more useful than supervisors (Wisse, van Eijbergen, Rietzschel, \& Scheibe, 2018).

\section{Task Performance}

Task performance is explained as in role performance (Kehoe, Lepak, \& Bentley, 2018). Task performance point out technical features of a worker's job (Zellars, Perrewé, Rossi, Tepper, \& Ferris, 2008). It exposes personal performance of the tasks required in job (Pflum, \& Gooding, 2018). 
Assignment actions positively lend in the direction of conversion of raw materials into finishing goods or services (Wright, Lipszyc, Dupuis, Thayapararajah, \& Schachar, 2014).

Zia-ud-Din, Shabbir, Asif, Bilal, and Raza, (2017) has explained that leadership of the organization play a vital role in enhancing the employee's performance such as Task Performance. Task performance of the employees is the important element in success of an organization. Organ and Paine (1999) has explained the job performance as "part and parcel of the work flow that transforms materials, information, and inputs of energy into outputs in the form of goods and services to the external body." Task activities is generally differing from other jobs but discourse actions are always common to some works (Chiniara, \& Bentein, 2018).

\section{Conceptual Framework}

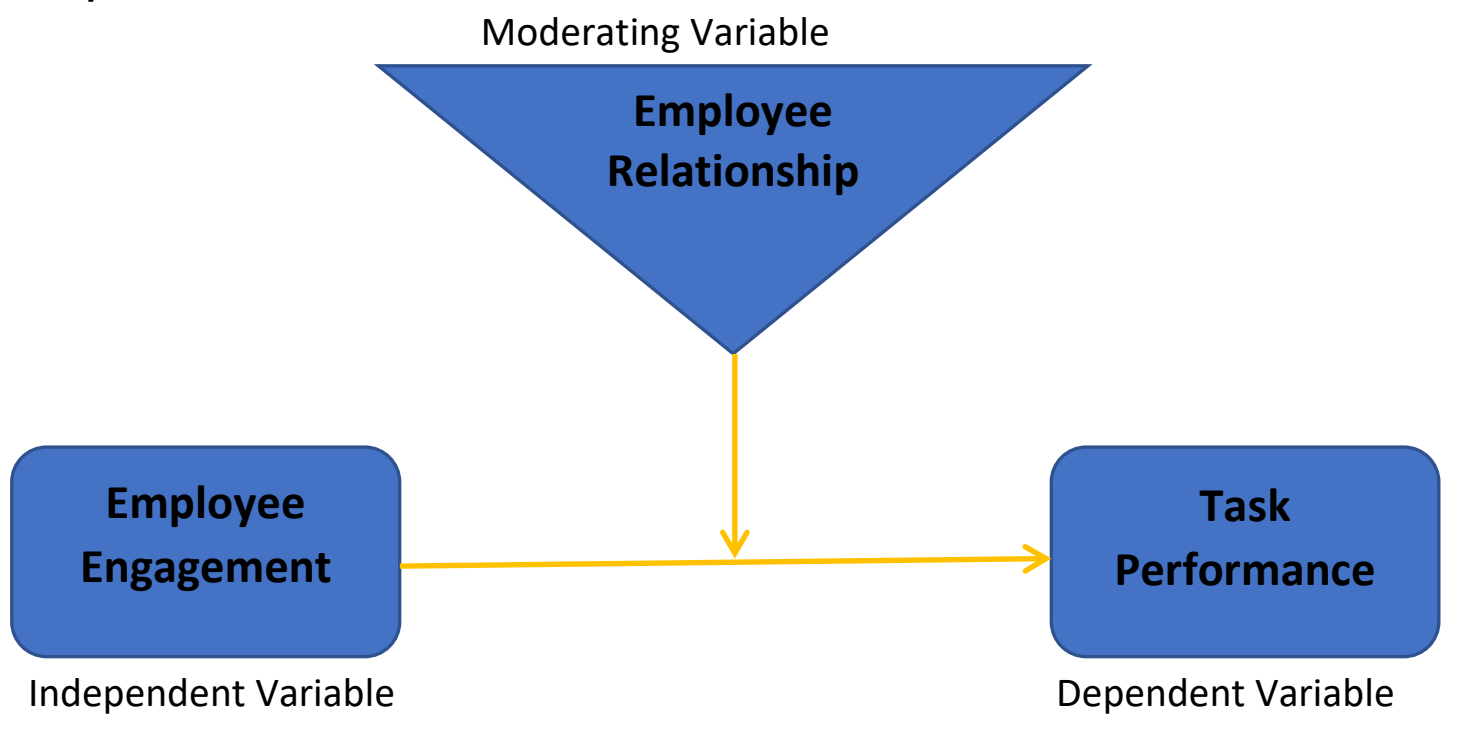

\section{Hypotheses}

By keeping in mind above mentioned objective following hypotheses are derived H1: EE has positive impact on task-performance.

H2: EE moderating the relationship between task-performance and employee engagement.

\section{Methodology}

\section{Scales and Questionnaire}

For measurement of variables different scales are used. The first section is demographic; two scales "nominal and ordinal" are used which consisted on four questions. The second session is consisted of questionnaire, 5 likert scale is used to measure these questionnaires. Employee Engagement is measured by using 12 questions and which adopted from Schaufeli et al. (2001). Task performance is also measured by 12 questions is adopted from Williams and Anderson (1991). 3 items are adopted from Liao, Chang, Cheng, and Kuo (2004) to measure Employee relationship

Population size for current study is 125 . Data is collected from the textile industries of Faisalabad. Questionnaire are designed and distribute in Mid and low-level textile managers convenience sampling technique is used to collect data. Each employee has given one questionnaire. 145 questionnaires distributed among the managers and 125 are justly endeavored with replying ratio of $86.20 \%$. Also checked the relationship of among each variable and strength between variable, 
INTERNATIONAL JOURNAL OF ACADEMIC RESEARCH IN BUSINESS AND SOCIAL SCIENCES

Vol. 8, No. 8, August 2018, E-ISSN: 2222-6990 @ 2018 HRMARS

Correlation test and Regression analysis is used. SPSS 21.0 software was used for testing the hypothesis.

\begin{tabular}{|c|c|c|}
\hline \multicolumn{3}{|c|}{ Demographic Factor } \\
\hline & $\mathrm{F}$ & $\%$ \\
\hline \multicolumn{3}{|l|}{ Gender } \\
\hline Male & 87 & 69.6 \\
\hline Female & 38 & 30.4 \\
\hline \multicolumn{3}{|l|}{ Age } \\
\hline $16-25$ & 41 & 32.8 \\
\hline $26-35$ & 65 & 52 \\
\hline $36-45$ & 11 & 8.8 \\
\hline Above 45 & 8 & 6.4 \\
\hline \multicolumn{3}{|l|}{ Qualification } \\
\hline Matric & 1 & .8 \\
\hline Intermediate & 3 & 2.4 \\
\hline Graduation & 26 & 20.8 \\
\hline Master & 80 & 64 \\
\hline MS/M,phill & 15 & 12 \\
\hline \multicolumn{3}{|l|}{ Department } \\
\hline HRM & 7 & 5.6 \\
\hline Finance & 45 & 36 \\
\hline Marketing & 46 & 36.8 \\
\hline IT & 3 & 2.4 \\
\hline Other & 24 & 19.2 \\
\hline
\end{tabular}

For Gender, there were 87 respondents lies in the group of males their percentage was 69.6\%. and 38 members in group of females with percentage of $30.4 \%$.

For the categories of Qualification, there were 80 members in the Master group and its percentage is $64 \%$ and 26 members that fell into category of graduation with the percentage of 20.8\%. Further 15, 3, and 1 respondents are MS/MPhil, Intermediate and Matric groups with cumulatively percentage is $15.2 \%$.

For the category of Age, there were 65 members that fall in the group of 26 to 35 with percentage of $52 \%, 41$ contributors are in the group of 16 to 25 with the percentage of $32.8 \%$. Further 11 and 8 contributors are in the group of 36 to 45 and above the age of 45 respectively with cumulatively percentage of $15.2 \%$.

For the categories of department, there were 46 contributors are in the group of Marketing with $36.8 \%, 45$ contributors are in the group of Finance with 36\%. Further 24, 7 and 3 contributors are in the group of others, HRM and IT with cumulatively percentage $27.2 \%$. 
INTERNATIONAL JOURNAL OF ACADEMIC RESEARCH IN BUSINESS AND SOCIAL SCIENCES Vol. 8, No. 8, August 2018, E-ISSN: 2222-6990 C 2018 HRMARS

\begin{tabular}{lccc}
\multicolumn{4}{c}{ Reliability Test } \\
\hline & $\begin{array}{c}\text { Employee } \\
\text { Engagement }\end{array}$ & $\begin{array}{c}\text { Employee } \\
\text { Relationship }\end{array}$ & $\begin{array}{c}\text { Work Task } \\
\text { Performance }\end{array}$ \\
\hline Cronbach's Alpha & .788 & .889 & .708 \\
\hline
\end{tabular}

Above Table shows the value of Cronbach's Alpha. Of Engagement, Employee Relationship and Task Performance of employee is respectively $0.788,0.889$ and 0.708 . The values of Cronbach's Alpha is more than 0.7 , which validates the reliability. It proves that the results are reliable.

\section{Correlations}

\begin{tabular}{|c|c|c|c|}
\hline & 1 & 2 & 3 \\
\hline \multicolumn{4}{|l|}{ Employee Engagement (EE) } \\
\hline Employee Relationship (ER) & $.790^{* *}$ & & \\
\hline Task Performance (TP) & $.829^{* *}$ & $.968^{* *}$ & \\
\hline
\end{tabular}

Above Table describes that Employee Engagement is significant association with Employee Relationship and Task performance with a value of .791 and 0.829 which is strongly significant at $1 \%$. Similarly, Employee Relationship is significantly linked with Task Performance with a value of .968.

\begin{tabular}{|c|c|c|c|c|c|c|}
\hline \multicolumn{7}{|c|}{ Regression Analysis } \\
\hline \multicolumn{7}{|c|}{ Model Summary } \\
\hline Model & $\mathrm{R}$ & R Square & $\begin{array}{l}\text { Adjusted R } \\
\text { Square }\end{array}$ & $\begin{array}{c}\text { Std. Error of the } \\
\text { Estimate }\end{array}$ & Durbi & latson \\
\hline $\begin{array}{l}1 \\
\text { a. Predi } \\
\text { b. Depe }\end{array}$ & $\begin{array}{l}.829^{a} \\
\text { ctors: (Constan } \\
\text { ndent Variable }\end{array}$ & $\begin{array}{l}.688 \\
\mathrm{TP}\end{array}$ & .685 & .24963 & & 1.879 \\
\hline \multicolumn{7}{|c|}{ ANOVA $^{a}$} \\
\hline Model & & Sum of Square & df & Mean Square & $\mathrm{F}$ & Sig. \\
\hline \multirow{3}{*}{1} & Regression & 16.89 & 1 & 16.897 & 271.164 & $.000^{b}$ \\
\hline & Residual & 7.66 & 123 & .062 & & \\
\hline & Total & 24.56 & 124 & & & \\
\hline
\end{tabular}

a. Dependent Variable: TP

b. Predictors: (Constant), EE 
INTERNATIONAL JOURNAL OF ACADEMIC RESEARCH IN BUSINESS AND SOCIAL SCIENCES

Vol. 8, No. 8, August 2018, E-ISSN: 2222-6990 @ 2018 HRMARS

Coefficients $^{a}$

\begin{tabular}{|c|c|c|c|c|c|c|}
\hline \multirow{2}{*}{\multicolumn{2}{|c|}{ Model }} & \multicolumn{2}{|c|}{ Unstandardized Coefficients } & \multirow{2}{*}{$\begin{array}{c}\text { Standardized } \\
\text { Coefficients } \\
\text { Beta } \\
\end{array}$} & \multirow[t]{2}{*}{$\mathrm{t}$} & \multirow[t]{2}{*}{ Sig. } \\
\hline & & B & Std. Error & & & \\
\hline \multirow{2}{*}{1} & (Constant) & .219 & .231 & & 1.986 & .005 \\
\hline & Emp.E & .915 & .056 & .829 & 16.467 & .000 \\
\hline
\end{tabular}

a. Dependent Variable: TP

In Table R square depicts that Employee engagement has $68.8 \%$ impact on Task Performance which shows that a positively effect employee engagement on task performance. To check the nature of correlation among the variables Durbin Watson is calculated, the value of Durbin Watson is 1.879 which is less than 2, it depicts that there is positive correlation between employee engagement and Task performance.

$$
\mathrm{Y}=\mathrm{bo}+\mathrm{bX}
$$

Task Performance $=.219+.829$ (Employee Engagement)

This equation shows that one unit change in employee engagement is increased the 1.048 units of task performance.

Written by Andrew F. Hayes, Ph.D. www.afhayes.com

Documentation available in Hayes (2013). www.guilford.com/p/hayes3

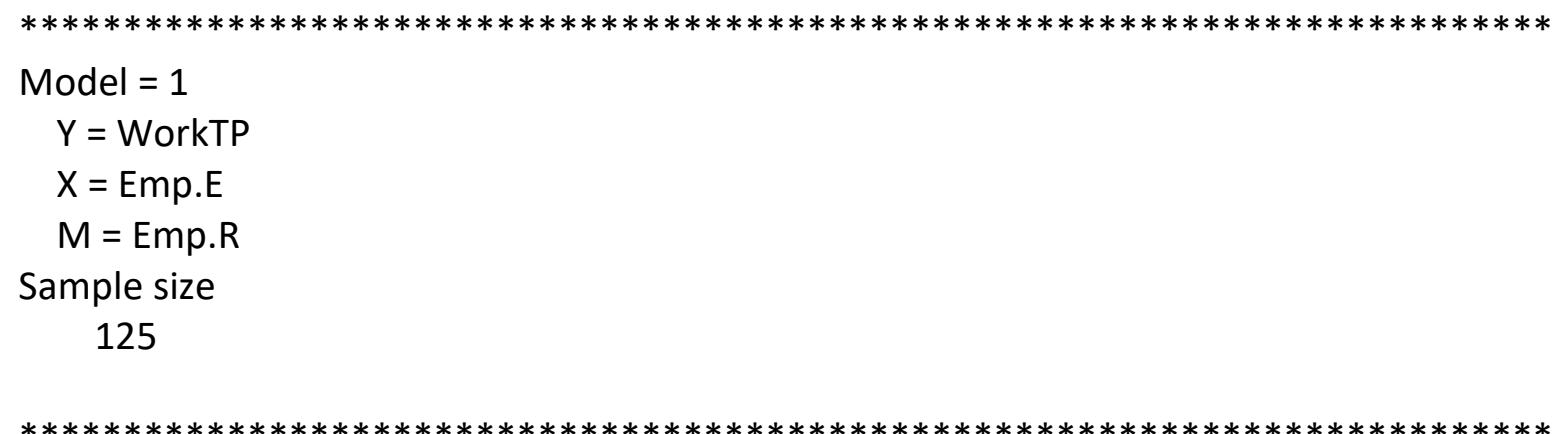

Outcome: WorkTP

Model Summary

$$
\begin{array}{cccccccc}
R & R-s q & M S E & F & d f 1 & d f 2 & p & \\
.9740 & .9487 & .0104 & 745.7943 & 3.0000 & 121.0000 & .0000
\end{array}
$$

Model

coeff se $t \quad p \quad L L C l \quad U L C l$

$\begin{array}{lllllll}\text { constant } & -.9310 & .6830 & -1.3631 & .1754 & -2.2832 & .4212\end{array}$

$\begin{array}{lllllll}\text { Emp.R } & 1.0696 & .1825 & 5.8606 & .0000 & .7083 & 1.4309\end{array}$

$\begin{array}{lllllll}\text { Emp.E } & .4847 & .1718 & 2.8216 & .0056 & .1446 & .8248\end{array}$

$\begin{array}{lllllll}\text { int_1 } & -.0775 & .0441 & -1.7558 & .0816 & -.1649 & .0099\end{array}$

Product terms key: 
INTERNATIONAL JOURNAL OF ACADEMIC RESEARCH IN BUSINESS AND SOCIAL SCIENCES

Vol. 8, No. 8, August 2018, E-ISSN: 2222-6990 @ 2018 HRMARS

int_1Emp.E $\quad X \quad$ Emp.R

R-square increase due to interaction(s):

R2-chng $F \quad d f 1 \quad d f 2 \quad p$

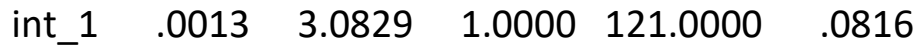

Conditional effect of $\mathrm{X}$ on $\mathrm{Y}$ at values of the moderator(s):

$\begin{array}{ccccccc}\text { Emp.R } & \text { Effect } & \text { se } & \mathrm{t} & \mathrm{p} & \mathrm{LLCl} & \mathrm{ULCl} \\ 3.4413 & .2179 & .0403 & 5.4095 & .0000 & .1382 & .2977 \\ 3.9321 & .1799 & .0375 & 4.7946 & .0000 & .1056 & .2542 \\ 4.4230 & .1418 & .0462 & 3.0722 & .0026 & .0504 & .2332\end{array}$

Values for quantitative moderators are the mean and plus/minus one SD from mean.

Values for dichotomous moderators are the two values of the moderator.

$* * * * * * * * * * * * * * * * * * * *$ ANALYSIS NOTES AND WARNINGS

Level of confidence for all confidence intervals in output:

95.00

NOTE: Some cases were deleted due to missing data. The number of such cases was:

5

------ END MATRIX ----

\section{Conclusion}

After analysis we reached to the conclusion that there is a significant association between work engagement and task performance. Higher the Employee engagement greater will be the task performance. This study makes contribution to ongoing research on a new leadership style i.e. hybrid leadership. Moreover, this study measures the influence of employee-engagement on task performance of with the catalyst of employee relation in textile sector organizations of Pakistan. Results shows that employee engagement is high when strong relation between the employee then the task performance of employee will also be high. According this study's result, there is positively association between employee engagement and task performance.

\section{Study Limitations}

The present-day investigation revealed that Employee engagement is very important in improving task performance of employees. However, this research is also having some certain limitations. Such as first limitation is that in current research, we have been checked the effect of employee engagement on task performance of employees, which has been testified by using samples of respondent from textile industries in major textile city Faisalabad, Pakistan. Further studies can be extended in different cities of Pakistan or can be in other countries or region to check the universal 
INTERNATIONAL JOURNAL OF ACADEMIC RESEARCH IN BUSINESS AND SOCIAL SCIENCES Vol. 8, No. 8, August 2018, E-ISSN: 2222-6990 @ 2018 HRMARS

effect of employee engagement across country. The sample size of current research is 125 future researchers may extent the size of this. We collect data from mid and low-level managers future researcher may also collect from top level managers. The future research might comprise on the sample of only female respondents and examine how it affects employee engagement.

\section{References}

Anitha, J. (2014). Determinants of employee engagement and their impact on employee performance. International journal of productivity and performance management, 63(3), 308.

Bailey, C., Madden, A., Alfes, K., \& Fletcher, L. (2017). The meaning, antecedents and outcomes of employee engagement: A narrative synthesis. International Journal of Management Reviews, 19(1), 31-53.

Baumeister, R. F., \& Leary, M. R. (1995). The need to belong: desire for interpersonal attachments as a fundamental human motivation. Psychological bulletin, 117(3), 497.

Besieux, T., Baillien, E., Verbeke, A. L., \& Euwema, M. C. (2018). What goes around comes around: The mediation of corporate social responsibility in the relationship between transformational leadership and employee engagement. Economic and Industrial Democracy, 39(2), 249-271.

Chiniara, M., \& Bentein, K. (2018). The servant leadership advantage: When perceiving low differentiation in leader-member relationship quality influences team cohesion, team task performance and service OCB. The Leadership Quarterly, 29(2), 333-345.

Eldor, L., \& Vigoda-Gadot, E. (2017). The nature of employee engagement: Rethinking the employee-organization relationship. The International Journal of Human Resource Management, 28(3), 526-552.

Global Perspectives 2016 - Employee Engagement Trends. (2016, November 01). Retrieved January 14, 2018, from https://orcinternational.com/download/global-perspectives-2016-employeeengagement-trends/

Huang, Y. H., Lee, J., McFadden, A. C., Murphy, L. A., Robertson, M. M., Cheung, J. H., \& Zohar, D. (2016). Beyond safety outcomes: An investigation of the impact of safety climate on job satisfaction, employee engagement and turnover using social exchange theory as the theoretical framework. Applied ergonomics, 55, 248-257.

Johnson, S., Robertson, I., \& Cooper, C. L. (2018). Well-Being and Employee Engagement. In WELLBEING (pp. 31-42). Palgrave Macmillan, Cham.

Kahn, W. A. (1990). Psychological conditions of personal engagement and disengagement at work. Academy of management journal, 33(4), 692-724.

Kehoe, R. R., Lepak, D. P., \& Bentley, F. S. (2018). Let's call a star a star: Task performance, external status, and exceptional contributors in organizations. Journal of Management, 44(5), 18481872.

Macey, W. H., \& Schneider, B. (2008). The meaning of employee engagement. Industrial and organizational Psychology, 1(1), 3-30.

Opoku-Dakwa, A., Chen, C. C., \& Rupp, D. E. (2018). CSR initiative characteristics and employee engagement: An impact-based perspective. Journal of Organizational Behavior.

Organ, D. W., \& Paine, J. B. (1999). A new kind of performance for industrial and organizational psychology: Recent contributions to the study of organizational citizenship behavior. 
INTERNATIONAL JOURNAL OF ACADEMIC RESEARCH IN BUSINESS AND SOCIAL SCIENCES

Vol. 8, No. 8, August 2018, E-ISSN: 2222-6990 @ 2018 HRMARS

Pflum, M. J., \& Gooding, D. C. (2018). Context matters: Social cognition task performance in psychometric schizotypes. Psychiatry research, 264, 398-403.

Potoski, M., \& Callery, P. J. (2018). Peer communication improves environmental employee engagement programs: Evidence from a quasi-experimental field study. Journal of Cleaner Production, 172, 1486-1500.

Reader, T. W., Mearns, K., Lopes, C., \& Kuha, J. (2017). Organizational support for the workforce and employee safety citizenship behaviors: A social exchange relationship. Human Relations, 70(3), 362-385.

Rupp, D. E., Shao, R., Skarlicki, D. P., Paddock, E. L., Kim, T. Y., \& Nadisic, T. (2018). Corporate social responsibility and employee engagement: The moderating role of CSR-specific relative autonomy and individualism. Journal of Organizational Behavior.

Schaufeli, W. B., Salanova, M., González-Romá, V., \& Bakker, A. B. (2002). The measurement of engagement and burnout: A two sample confirmatory factor analytic approach. Journal of Happiness studies, 3(1), 71-92.

Shabbir, M. A., Ishtiaq, Z., \& Zia-ud-Din, M. (2017). The Impact of Hybrid leadership on Employee performance in Textile Sector of Pakistan. International Journal of Academic Research in Business and Social Sciences, 7(4), 359-374.

Sias, P. M., Heath, R. G., Perry, T., Silva, D., \& Fix, B. (2004). Narratives of workplace friendship deterioration. Journal of Social and Personal Relationships, 21(3), 321-340.

Smothers, J., Doleh, R., Celuch, K., Peluchette, J., \& Valadares, K. (2016). TALK NERDY TO ME: THE ROLE OF INTELLECTUAL STIMULATION IN THE SUPERVISOR-EMPLOYEE RELATIONSHIP. Journal of Health \& Human Services Administration, 38(4).

Supanti, D., Butcher, K., \& Fredline, L. (2015). Enhancing the employer-employee relationship through corporate social responsibility (CSR) engagement. International Journal of Contemporary Hospitality Management, 27(7), 1479-1498.

Trends in Global Employee Engagement - Report | Retrieved January 14, 2018, from http://www.aon.com/engagement17/

Wisse, B., van Eijbergen, R., Rietzschel, E. F., \& Scheibe, S. (2018). Catering to the needs of an aging workforce: The role of employee age in the relationship between corporate social responsibility and employee satisfaction. Journal of Business Ethics, 1-14.

Wright, L., Lipszyc, J., Dupuis, A., Thayapararajah, S. W., \& Schachar, R. (2014). Response inhibition and psychopathology: A meta-analysis of go/no-go task performance. Journal of Abnormal Psychology, 123(2), 429.

Yu, M. C., Mai, Q., Tsai, S. B., \& Dai, Y. (2018). An Empirical Study on the Organizational Trust, Employee-Organization Relationship and Innovative Behavior from the Integrated Perspective of Social Exchange and Organizational Sustainability. Sustainability, 10(3), 864.

Zia-ud-Din, M., Shabbir, M. A., Asif, S. B., Bilal, M., \&Raza, M. (2017). Impact of Strategic Leadership on Employee Performance. International Journal of Academic Research in Business and Social Sciences, 7(6), 8-22. 